\title{
Coitus Interuptus sebagai Upaya Pencegah Kehamilan Dalam Hukum Islam (Studi Komparatif Menurut Al Gazali dan Ibnu Al-Qayyim)
}

\author{
Tomi Agustian dan Lentiara Putri \\ IAIN Curup, Bengkulu, Indonesia \\ tomiagustian48@iaincurup.ac.id, lentiara@unib.ac.id
}

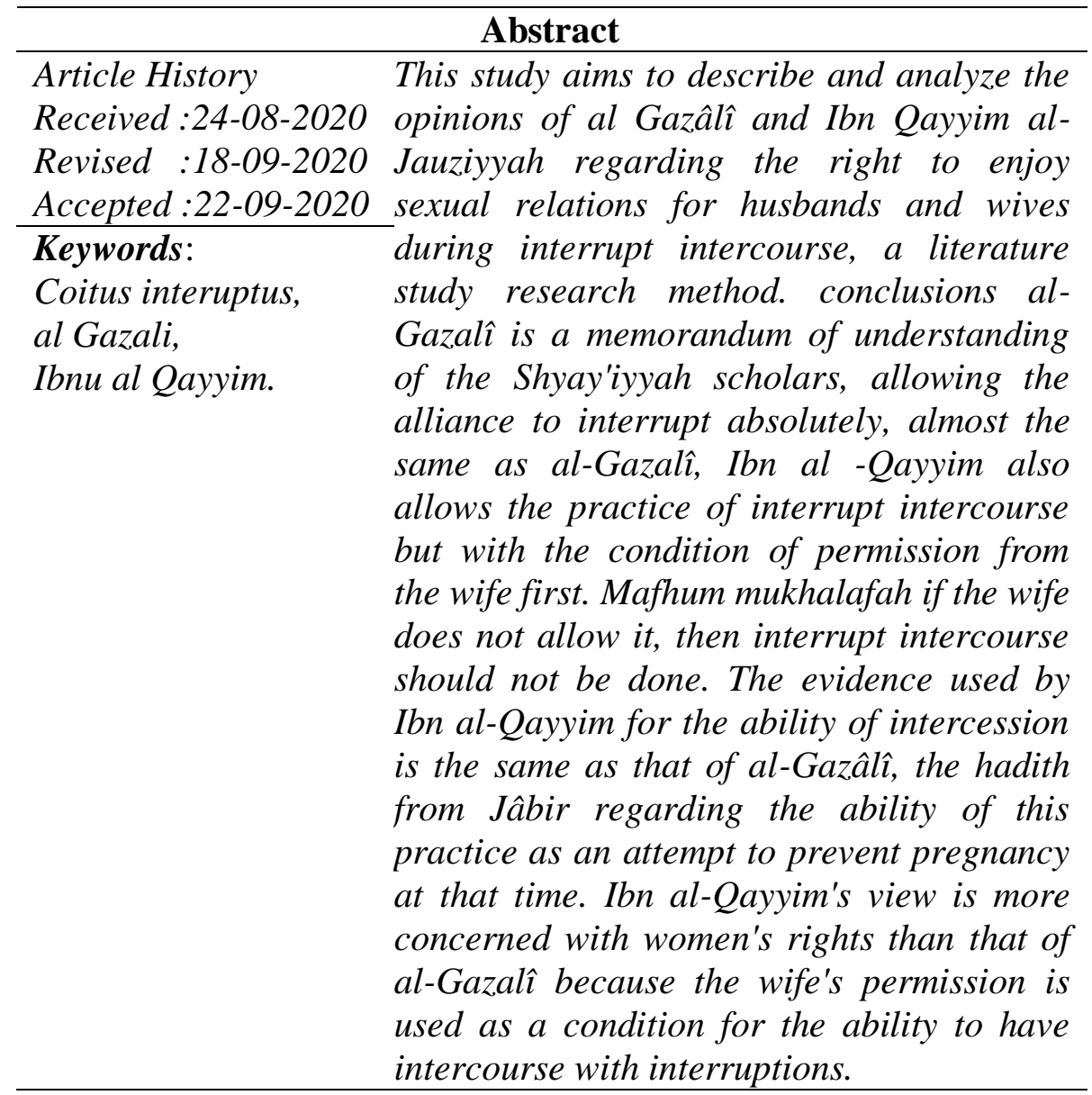

\section{Pendahuluan}

Menurut fitrahnya manusia dilengkapi Tuhan dengan kecenderungan seks (libido seksualitas). Rahmat Hakim, 2000:15). Seks ini pada saat-saat tertentu dapat menagih seperti halnya kebutuhan manusia akan makan, minum dan bernafas. Oleh karena itu 
diperlukan wadah yang benar dan legal untuk menyalurkan dan mengekspresikan gejolak seksual tersebut. Islam sebagai agama yang universal dan komprehensif tidak menafikan hajat ini dan mengaturnya melalui prosedur perkawinan. Dengan perkawinan, maka kebutuhan biologis ini dapat tersalurkan pada proporsi yang tepat dan sah serta sesuai dengan derajat kemanusiaan. Muslim berkeyakinan bahwa Islam tidak dapat dipisahkan dari negara islam itu adalah ajaran-ajaran yang meliputi kaidah kaidah muamalah (hubungan manusia dengan sesama manusia dan ibadah khusus (hubungan manusia dengan Tuhan. (Tomi Agustian, 2020. 8). Adapun di antara tujuan persyari'atan perkawinan dalam Islam adalah untuk melanjutkan keturunan, menghindari zina, menumbuhkan rasa cinta kasih dalam keluarga, menghormati sunah Rasul dan penyaluran hasrat seksual.( Kamal Mukhtar, 1993: 12-15)

Disamping itu Islam juga melukiskan perkawinan sebagai perikatan yang kokoh (mîsâqan galîzân). (Q.S An-Nisâ (4): 21) sebagai ikatan yang kokoh, perkawinan ini dituntut untuk menghasilkan suatu kemaslahatan yang komplek, yang berorientasi pada terwujudnya keluarga mawaddah wa rahmah. Sejalan dengan hal ini, tujuan tersebut dalam al-Qur`an diapresiasikan dengan indah.

$$
\text { ومن آيته ان خلق لكم من انفسكم ازو اجا لتسكنوا اليها وجعل بينكم مودة ورحمة }
$$

(Q.S Ar-Rum (30): 21)

Dari ayat di atas, dapat diambil kesimpulan bahwa kunci kebahagiaan dalam membangun sebuah keluarga adalah tercapainya mawaddah wa rahmah. Mawaddah dapat diartikan dengan hal-hal yang dapat membangkitkan kemauan untuk memadu kasih sayang atau nafsu birahi yang dilengkapi dengan rahmah, yaitu rasa saling menyantuni antara suami istri lantaran jalinan kasih sayang. Rahmah inilah yang akan menjadi jaminan kelanjutan hidup berumah tangga yang tentram sampai akhir hayat, karena rahmah menjangkau jauh melewati libido dan instink seksual semata. (Nine Surtiretna, 2001:5)

Coitus interuptus atau senggama terputus adalah suatu tindakan mencabut batang zakar dari vagina sewaktu akan terjadi pengeluaran sperma (ejakulasi), sehingga sperma ditumpahkan di luar vagina. Cara demikian ini dalam Islam disebut 'azl. (Nine Surtiratna, 2001: 282) Coitus interuptus sebagai metode pencegahan kehamilan sudah diterima cukup luas di kalangan masyarakat muslim dan ada bukti 
kuat bahwa tindakan ini sudah dilakukan oleh sahabat Nabi. Hal ini berulang-ulang dilaporkan kepada Nabi, dan beliau tidak melarangnya. Begitu juga al-Qur`an yang saat itu sudah turun juga tidak melarang. Berikut ini sebagian hadis yang dijadikan dasar legitimasi upaya pencegahan kehamilan (Imam Muslim ibn al Hajjaj al Quraisy al Naysaburi, Sahîh Muslim, I: 610. Hadis 15 dari Jâbir ibn 'Abdillâh.)

$$
\text { عن جابربن عبد الله قال:كان نعزل على عهد رسول الله عليه الصلاة والسلام و القران ينزل }
$$

Hadis ini mengungkapkan dengan jelas bahwa para sahabat biasa mempraktekkan coitus interuptus tanpa ada larangan dari Nabi ataupun al-Qur`an. Secara eksplisit hadis ini memperkenalkan ketetapan tentang kehalalan tindakan coitus interuptus.

Selanjutnya, persoalan yang mengemuka berkaitan dengan upaya pencegahan kehamilan dengan coitus interuptus dalam hukum Islam adalah bahwa jika senggama terputus merupakan cara yang dikehendaki oleh laki-laki. Sementara itu ada kecenderungan umum bahwa dalam hubungan seksual yang lebih menikmati adalah pihak suami, sedangkan pihak istri hanya berkewajiban melayani. Permasalahan apakah istri sudah bisa mencapai orgasme atau tidak adalah nomor kesekian.

Merespon masalah di atas, di antara penganut paham ortodok, pengikut mazhab Syafi'i sajalah yang cenderung membolehkan dilakukannya coitus interuptus tanpa syarat, yaitu dilakukan tanpa persetujuan istri. Argumen yang mereka bangun adalah bahwa coitus interuptus itu sendiri bukan merupakan perbuatan terlarang, maka tidak perlu dikenakan syarat atas perbuatan tersebut. (Hâmid, 2016:149) Lebih lanjut, al Gazâlî, tokoh termashur fiqh mazhab Syafi'i mengatakan dengan jelas kebolehan coitus interuptus. Menurut al Gazâlî, bahwa tidak ada dasar yang melarang coitus interuptus, sebab larangan dalam Islam hanya bisa diterapkan dengan ketentuan yang jelas dalam al-Qur'an dan hadis atau dengan membuat analogi dengan teks tersebut (qiyas). (Hâmid, 2016:150)

Berbeda dengan mazhab Syafi'i, Imam al Kâsâniy, penganut mazhab Hanafi, mengatakan bahwa makruh hukumnya bagi suami untuk melakukan coitus interuptus dengan istrinya (wanita merdeka) tanpa seijinnya. Karena hubungan seksual yang berakhir dengan ejakulasi adalah penyebab terjadinya pembuahan dan wanita 
memiliki hak untuk melahirkan anak-anaknya. Dengan ejakulasi di luar vagina maka pembuahan tidak akan terjadi. (Bakar, 2016: 495)

Senada dengan pandangan mazhab Hanafi, mazhab Hanbali termasuk Ibnu al Qayyim menekankan perlunya ijin dari pihak istri. (Ibnu Qayyim al Jauziyyah, 1992: 142) Alasan mereka ada dua. Pertama, anak adalah hak yang dimiliki oleh wanita merdeka, dengan melakukan coitus interuptus maka dengan sendirinya pembuahan tidak akan terjadi. Dikarenakan sperma yang keluar disaat ejakulasi ditumpahkan di luar vagina, secara otomatis hak wanita merdeka untuk mendapatkan anak akan hilang dan kedua, wanita tersebut mungkin akan merasa sakit sebagai akibat coitus interuptus. Rasa sakit itu terutama karena kurangnya kenikmatan yang diperolehnya dalam hubungan seksual. Di sini, kepuasan seksual bagi istri tergantung pada kesempurnaan senggama, yang tidak mungkin diperoleh dalam senggama terputus.

Dari ilustrasi di atas, bahwa perbedaan diantara ulama atas syarat yang mengiringi kebolehan coitus interuptus menarik untuk dikaji ulang, mengingat adanya hak-hak perempuan, di mana ruang untuk memilih antara ya dan tidak telah dikesampingkan. Maka dari sinilah, penyusun sangat tertarik dan antusias untuk membahas dalam sebuah karya ilmiah jurnal melalui studi analisis komparatif terhadap pendapat al Gazâlî dan Ibnu al Qayyim, di mana, disamping sisi ketokohan al Gazâlî dan Ibnu al Qayyim sebagai figur dan pemikir besar yang mampu berbicara pada zamannya bahkan sampai sekarang pendapat dan pandangannya masih hangat dibicarakan, juga adanya perbedaan pandangan antara keduanya tentang ada tidaknya ijin dari pihak perempuan (istri) yang menjadi syarat atas kebolehan coitus interuptus.

Dari sekian langkah yang penyusun ambil sebagai proses awal dalam penyusunan karya tulis ilmiah ini adalah melakukan telaah pustaka terhadap karya-karya tulis yang berkaitan dengan obyek penelitian ini. Di IAIN Raden Intan Lampung hanya terdapat satu skripsi yang penulis temukan yang mempunyai tema hampir sama dengan tema yang penyusun teliti. Skripsi yang penulis maksud ini berjudul "'Azl sebagai upaya pencegahan kehamilan : Studi atas pandangan Ibnu Hazm “.(Nunuk Inayatul Ulya, 2014) tidak Dalam skripsinya ini, penulisnya, membahas coitus interuptus hanya dalam pandangan Ibn Hazm saja, ia tidak mengekspolasi sama sekali pendapat al Gazâlî dan Ibnu al Qayyim. 
Kajiannya lebih ditekankan pada penelitian terhadap dalil-dalil yang digunakan Ibnu Hazm untuk menguatkan pendapatnya yang kontroversial, berbeda dengan mayoritas ulama. Hak-hak dasar perempuan yang berkaitan dengan coitus interuptus dalam penelitiannya kurang banyak disinggung."Sebagai penganut mazhab Zâhiri, yang berpegang pada Zâhiru Nas al Qur'an dan al hadis, Ibnu Hazm mengeluarkan larangan mutlak terhadap pelaksanaan coitus interuptus sebagai upaya pencegahan kehamilan dengan alasan bahwa coitus interuptus sama dengan pembunuhan bayi terselubung (al maw'udat al sugra)."

Sementara itu, pembahasan tentang pendapat al Gazâlî dapat ditemukan dalam kitab Ihyâ 'Ulûm al Dîn. Dalam kitab ini al Gazâlî mengemukakan argumen-argumennya tentang coitus interuptus. $\mathrm{Al}$ Gazâlî mengawali pendapatnya dengan mengemukakan bahwa pelarangan terhadap coitus interuptus tidak ada dasarnya. (Hâmid. 2016: 151) Ia juga menjelaskan bahwa praktek ini tidak dianjurkan akan tetapi sah menurut hukum. Coitus Interuptus sebagai upaya pencegahan kehamilan dihukumi makruh dengan alasan bahwa yang dikeluarkan (air mani laki-laki) dibuang dengan sia-sia. Disamping itu, ia juga menjelaskan tentang tata cara melakukan hubungan seksual. Dalam penelitian ini, buku tersebut memegang peranan yang sangat penting sebagai salah satu bahan rujukan utama.

Sedangkan pembahasan tentang pendapat Ibnu al Qayyim dapat dilihat dalam karyanya, seperti Zâd al Ma'âd. Dalam kitab ini, disamping ia mengemukakan pendapatnya sendiri tentang coitus interuptus, Ibnu al Qayyim juga mengakomodir pendapat dan dasardasar argumen ulama-ulama lain sebagai perbandingan terhadap pendapatnya. (Ibnu Qayyim al Jauziyyah, Zâd., 1992. 140-146)

Berdasarkan hasil penelitian B.F Musallam yang diungkapkan dalam bukunya Seks dan Masyarakat dalam Islam bahwa masalah coitus interuptus tidak hanya menyedot perhatian kaum moralis dan agamawan saja, tetapi para ahli sejarah ekonomi dan demografi pun juga antusias untuk memperhatikan masalah tersebut, sehingga masalah ini menjadi bahan studi dan pembicaraan serta perdebatan terutama dari segi keberadaannya, hukum dan prosesnya. Dalam karyanya ini, B.F Musallam juga membuktikan bahwa pembatasan kelahiran adalah sebagai sebuah pola yang sudah ada di dunia Islam pada abad pertengahan. (Rahmani Astuti, 2012: 1-3) Ia membahas secara komprehensif tentang pandangan ahli hukum Islam dari 
peradabaan muslim klasik. Pencegahan kelahiran dalam buku yang judul aslinya adalah Sex and Society in Islam ini memberikan titik tekan pada segi pencegahan kehamilan dan aborsi ( pengguguran kandungan ) dengan mengaitkan hak-hak wanita dalam praktek tersebut.

Kalau ditelusuri dalam literatur-literatur klasik, banyak juga yang membahas tentang 'azl (coitus interuptus). Di antaranya al Muwatta karya Imam Mâlik, dalam kitab ini Imam Mâlik mensahihkan tujuh hadis mengenai coitus interuptus. Ia menyatakan pendapatnya bahwa coitus interuptus tidak boleh dilakukan tanpa persetujuan istri yang merdeka. ( Mâlik bin Anas, 596) Pembahasan coitus interuptus juga dapat ditemukan dalam kitab Badâi' al Sanâi' fi Tartîbi asy Syarâ'i karya al Kâsâniy. Dalam kitab tersebut, al Kâsâniy juga menyatakan kemakruhan coitus interuptus jika Sedangkan pembahasan tentang hak-hak reproduksi perempuan ditulis oleh Masdar F. Mas'udi dengan judul Islam dan Hak-hak Reproduksi Perempuan. Buku ini banyak menyoroti masalah-masalah penting dalam kehidupan manusia terutama yang berkaitan dengan hak-hak perempuan dalam sebuah perkawinan yang selama ini terkesan dipasung, seperti hak memilih pasangan hidup, (Masdar F. Mas'udi, 2000: 95-114) hak mendapatkan kepuasan seksual. Pengarang menyajikannya lewat gaya dialog sehingga memudahkan pembaca untuk menyelami suatu tema pembahasan. Akan tetapi kajian tentang hubungan seksual suami istri mendapat porsi yang sedikit karena pada dasarnya buku ini memang tidak diformulasikan secara khusus membahas masalah tersebut.

Zaitunah Subhan dalam bukunya yang berjudul Tafsir Kebencian, menawarkan wacana kemitrasejajaran lelaki dan perempuan dalam perspektif Islam (al-Qur'an dan Hadis), atau lebih khusus lagi kemitrasejajaran dan atau relasi laki-laki dan perempuan menurut perspektif para mufassir Indonesia, mufassir ulama klasik dan para feminis Muslim. Di sini juga dijelaskan mengenai hubungan kodrat perempuan dan kemitrasejajaran dalam hal memilih jodoh, menceraikan, hubungan seksual, mengasuh dan merawat anak, dan mengatur urusan rumah tangga. Pembahasan mengenai kemitrasejajaran hubungan seksual dalam buku ini hanya dibahas secara umum saja, sedangkan coitus interuptus tidak mendapatkan porsi sama sekali. (Zaitunah Subhan, 1999: 132-154)

Setelah mengamati dan meneliti kajian-kajian yang ada, sejauh 
yang penyusun ketahui, kajian secara spesifik yang bersifat komparatif terhadap pandangan al Gazâlî dan Ibnu al Qayyim tentang coitus interuptus belum pernah ada yang mengkajinya. Di ruang inilah penelitian ini mencoba mencari titik urgensinya. Meskipun demikian, beberapa studi di atas akan sangat membantu penyusun dalam mengkomparasikan pandangan al Gazâlî dan Ibnu al Qayyim. Dari pemaparan latar belakang masalah di atas, maka masalah pokok yang menjadi bahasan dalam studi ini adalah sebagai berikut: Bagaimana pendapat al Gazâlî dan Ibnu Qayyim al Jauziyyah tentang coitus interuptus sebagai upaya pencegahan kehamilan?. Bagaimana pendapat al Gazâlî dan Ibnu Qayyim al Jauziyyah tentang hak-hak menikmati hubungan seksual bagi suami dan istri dalam coitus interuptus?

\section{Metode Penelitian}

Dalam penyusunan karya ilmiah, tidak akan terlepas dari penggunaan metode. Sebab metode merupakan cara bertindak agar kegiatan penelitian dapat terlaksana secara baik, ter-arah dan mencapai hasil secara optimal. Anton Bakker, 1999: 11) Jenis Penelitian yang penyusun gunakan dalam pembahasan ini adalah Penelitian Kepustakaan. penelitian kepustakaan (library research), dan sumber data yang diambil dalam penelitian tersebut yaitu meneliti pendapat al Gazâlî dan Ibnu al Qayyim tentang coitus interuptus melalui buku-buku dan kitab-kitab yang telah memberikan informasi dan membahas obyek kajian, dengan pendekatan normatif, Pengumpulan data dilakukan dengan melacak buku-buku dan kitabData primer yang digunakan sebagai acuan dalam skripsi ini adalah kitab Ihyâ 'Ulûm al Dîn dan kitab Zâd al Ma'âd. Kitab Ihyâ 'Ulûm al Dîn adalah karangan al Gazâlî. sekunder yang digunakan adalah I'lâm al Muwaqqi'în karya Ibnu al Qayyim, Fath al Bâriy karya Ibnu Hajar, al Mugnî karya Ibnu Qatâdah, Seks dan Masyarakat karya B.F Musallam, Islam dan Hak-hak Reproduksi karya Masdar F. Mas'udi, Tafsir Kebencian karya Zaitunah Subhan, Kesehatan Reproduksi : Panduan bagi Perempuan karya Zohra Andi Baso dan Judi Andi Baso - Menggunakan analisis komparatif bertujuan untuk mencari titik persamaan dan perbedaan antara al Gazâlî dan Ibnu al Qayyim tentang coitus interuptus untuk kemudian dicari mana yang lebih menghargai hak-hak seksual perempuan. 


\section{Coitus Interuptus Menurut Fiqh}

Syari'ah Islam merupakan rangkuman ajaran yang komprehensif dan mengandung tata nilai yang bersifat universal, abadi dan yang menjangkau semua segi kehidupan. Ajaran tersebut pada prinsipnya adalah aturan-aturan Allah SWT tentang tata kehidupan seorang muslim dalam segala aspeknya. Peraturanperaturan itu sebagian berupa norma-norma yang tidak dapat berubah dan sebagian lagi berupa pedoman-pedoman umum yang sifatnya elastis dan fleksibel Pada dataran aplikasinya, Syari'ah memiliki kapasitas menampung kebhinekaan yang menjadi ciri khas umat manusia dan kemampuan akomodatif terhadap perubahan sosial. (Munawir Sjadzali, ,1996:117)

Mahmud Syaltut dalam bukunya al-Islâm 'Aqîdah wa Syarî'ah mendefinisikan syari'âh sebagai peraturan yang diturunkan Allah kepada manusia agar dipedomi dalam berhubungan dengan Tuhannya, dengan sesamanya, dengan lingkungannya dan dengan kehidupan. (Mahmud Syaltut, 1966:12) Pesan-pesan Tuhan melalui syari'at tersebut bersifat mutlak dan idealis. Oleh karena itu, untuk menangkap dan menerapkan pesan-pesan syari'at yang bersifat mutlak dan idealis tersebut, agar nantinya dapat menjawab permasalahan dan kebutuhan manusia, diperlukan adanya pemahaman dan interpretasi terhadap pesan tersebut, yang kemudian dalam hukum Islam, hal ini dinamakan dengan fiqh.

Secara etimologis fiqh menunjukkan arti memahami, mengerti dan menebus hakikat perkara. (Muhammad Ahmad, 1997:21) Namun berbeda dengan 'ilm yang artinya mengerti. Ilmu bisa diperoleh secara nalar atau wahyu, fiqh menekankan pada penalaran, meskipun penggunaannya nanti terikat dengan wahyu. (Ahmad Rafiq, 1998: 5) Sedangkan dalam pengertian terminologis, fiqh adalah hukum-hukum syara' yang bersifat praktis ('amaliyah) yang diperoleh dari dalil-dalil yang rinci. (Abdul al-Wahhâb, 2002: 4) Antara syari'ah dan fiqh mempunyai hubungan yang erat. Karena fiqh adalah formula yang dipahami dari syari'ah. Syari'ah tidak bisa dijalankan dengan baik, tanpa dipahami melalui fiqh. Fiqh sebagai hasil memahami, sangat dipengaruhi oleh tuntutan ruang dan waktu yang melingkupi faqîh yang menformulasikannya. (Ahmad Rofiq, : 5) Karena itulah, sangat wajar jika kemudian, terjadi perbedaan-perbedaan dalam rumusan mereka. 
Dalam bingkai sejarah perkembangan hukum Islam, perbedaan pendapat mengenai penetapan hukum beberapa masalah hukum, telah terjadi di kalangan para sahabat Nabi SAW, ketika beliau masih hidup. Tetapi perbedaan itu segera dapat dipertemukan dengan mengembalikannya pada Nabi. Setelah beliau wafat, maka sering timbul di kalangan sahabat perbedaan pendapat dalam menetapkan hukum terhadap masalah tertentu. Perbedaan pendapat di kalangan sahabat, tidak banyak jumlahnya, karena masalah yang terjadi waktu itu tidak sebanyak yang timbul pada generasi berikutnya.

Samping disebabkan oleh faktor yang bersifat manusiawi, juga oleh faktor lain karena adanya segi-segi khusus yang bertalian dengan agama. (Huzaemah Tahido Yanggo, , 1997: 51) Diantara faktor itu adalah karena obyek kajian yang masih gelap, perbedaan dalam memahami dan menangkap nas, perbedaan keinginan dan kecenderungan, perbedaan orientasi, taklid kepada para pendahulu, perbedaan kapasitas intelektual, cinta akan kekuasaan.

Mengetahui sebab-sebab terjadinya perbedaan pendapat para imam mazhab dan para ulama fiqh, sangat penting untuk membantu kita, agar keluar dari taklid buta, karena kita akan mengetahui dalildalil yang mereka pergunakan serta jalan pemikiran mereka dalam menetapkan hukum suatu masalah.

Penyusun akan menjabarkan pendapat al-Gazâlî dan Ibnu alQayyim tentang coitus interuptus serta meneliti dalil serta argumen yang mereka bangun, kemudian penyusun akan membandingkannya dengan memetakan persamaan dan perbedaan diantara keduanya.

\section{Coitus Interuptus dalam Pandangan al Gazâlî}

Nama lengkap Imâm al-Gazâlî adalah Abû Hâmid Muhammad bin Muhammad bin Muhammad al-Gazâlî at-Tûsi. Al-Gazâlî juga memiliki beberapa alam laqab (julukan) yang terkenal dalam dunia Islam, misalnya saja, Hujjatul Islâm, Zainuddîn at-Tûsi (Penghias agama) (Yûsuf al-Qardawi, 1996: 39) , al-Faqîh asy-Syâfi' î, dan Bahrun Mugriq. (Basyuni Madjidi, 1997: 79). Lihat juga dalam H.M. Zurkani Jahja, Teologi., hlm. 71Disamping itu ia juga digelari dengan the Spinner yang berarti pemintal atau penenun. (Idris Shah, 1989: 147) Al Gazâlî dilahirkan pada tahun 1058 M/450 H di desa Gazâlah, di Tûs (sekarang dekat Meshed), sebuah kota di Persia. Daerah tersebut sekarang masuk dalam propinsi Khurasân, Iran. Beliau meninggal di Tûs pada hari Senin tanggal 14 Jumadil Akhir tahun 
$505 \mathrm{H}$ atau 19 Desember $1111 \mathrm{M}$ pada usia 55 tahun dan dimakamkan di Thaburan, wilayah Tûs. (Abû Hâmid Al-Gazâlî, 2001: 111).

Al-Gazâlî hidup pada masa pemerintahan 'Abbasiyah II. Disamping terkenal sebagai salah satu sentral sufisme, al-Gazâlî adalah seorang teolog Muslim dan faqîh abad pertengahan. Pada masa al-Gazâlî, selain terjadi disintegrasi di bidang politik umat Islam, juga di bidang sosial keagamaan. Pada waktu itu, keadaan umat Islam terpecah-pecah menjadi beberapa golongan mazhab fiqh dan aliran kalam, fanatisme dan pendewaan terhadap mazhab yang dianut semakin ekstrim dan menguat karena para tokoh agama dan penguasa ikut intervensi dalam hal ini.

Sebagai seorang ulama mazhab Syâfi'î, al-Gazâlî dihadapkan pada sebuah kondisi yang mana doktrin-doktrin fiqh dan teologi mazhab yang ia anut berpengaruh sangat besar terhadap pemikiran alGazâlî, baik dalam lingkup fiqh maupun teologi. Demikian besar pengaruh doktrin-doktrin tersebut sehingga tidak heran bila dalam masalah fiqh, misalnya tentang pembolehan tindakan pencegahan kehamilan (coitus interruptus), al-Gazâlî tampaknya mengikuti apa yang menjadi pandangan mayoritas yang dianut oleh mazhabnya, yaitu membolehkan tindakan coitus interruptus secara mutlak walaupun tanpa seizin isteri.

Iklim dan kondisi sosial politik masyarakat pada saat itu juga sangat mendukung pada pandangan al-Gazâlî khususnya tentang tindakan pencegahan kehamilan, karena pada saat itu pemerintahan dipegang oleh orang-orang yang kebetulan se-ideologi dengan alGazâlî yakni penganut mazhab Syâfi'î. Mayoritas masyarakat pada saat itu juga tidak jauh berbeda dengan para penguasa dalam hal bermazhab.

Pada pembahasan sebelumnya telah dijelaskan sekilas tentang argumentasi al-Gazâlî (bab I) mengenai pembolehan coitus interruptus secara mutlak (tanpa persetujuan isteri) dan beberapa alasan pencegahan kehamilan (bab II). Sebelum melangkah pada pembahasan tentang sejauh mana dan apa saja hak-hak suami istri yang terkait dengan coitus interuptus dalam pandangan al-gazâlî, terlebih dahulu dijelaskan tentang argumen al-Gazâlî serta dalil yang digunakan al-Gazâli dalam membolehkan secara mutlak coitus interuptus itu sendiri. Hal ini penyusun anggap penting untuk diteliti karena untuk menjadi pintu masuk membahas hak hak perempuan 
yang ada hubungannya dengan coitus interuptus. Disamping itu, karena tidak semua ulama fiqh membolehkan praktek ini. Adapun pendapat mereka mengenai hal ini yaitu:

Membolehkan secara mutlak, tanpa ada syarat yang mengiringinya. Melarang secara mutlak.

Boleh dilakukan dengan persetujuan wanita dan tidak boleh tanpa persetujuan wanita. Pendapat ini hanya melarang menyakiti perasaan wanita, bukan coitus interuptusnya.

Boleh dilakukan terhadap budak perempuan, tidak terhadap istri yang merdeka. (Abdul Aziz, 1999 : 47)

Masih dalam kontroversi ulama menyikapi praktek coitus interuptus, al-Gazalî yang notabene sebagai Syâfi'iyah, berpendapat coitus interuptus boleh secara mutlak karena tidak ada dasar (alQur'an dan hadis) yang melarang praktek ini. Sebab larangan dalam Islam hanya bisa diterapkan dengan mengemukakan teks asli (nas), yaitu ketentuan yang jelas dalam al-Qur'an atau dalam hadis, atau dengan memuat analogi dengan teks tersebut. Dalam hal ini al-Gazâlî berpendapat, tidak terdapat teks semacam itu, juga tidak ada prinsipprinsip lain yang menyatakan larangannya. ( Abû Hâmid al Gazâlî, Ihyâ., II: 149) Karena itu, hukum dari tindakan tersebut harus dikembalikan kepada kaidah hukum Islam (qâ'idah fiqhiyah) yang menyatakan:

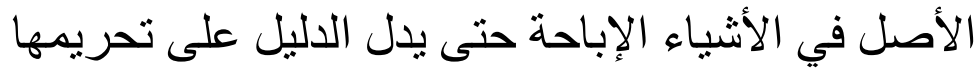

Dalam Ihyâ, al-Gazâlî menyatakan halalnya coitus interruptus secara bebas. Dalam keterangannya lebih lanjut, ia menegaskan bahwa coitus interuptus bukanlah pembunuhan dan tidak seperti aborsi atau pembunuhan anak, di mana terdapat kejahatan terhadap janin yang telah berbentuk atau anak yang telah lahir. (Al-Gazâlî, Ihyâ., II: 149-150)

Argumen pokok al-Gazâlî adalah keabsahan dari tindakan penarikan penis itu sendiri. Dia mengemukakan hal ini semata-mata didasarkan pada pemahamannya akan biologi reproduksi. Dia mengemukakan bahwa kalau pengguguran kandungan dan pembunuhan bayi dapat dipandang sebagai kejahatan atau tindak pidana melawan mahluk hidup (yang berwujud), maka pencegahan kehamilan merupakan sesuatu yang berbeda. (B.F Musallam, S, 1985:13). Hal ini dapat dilogikakan dengan proses terbentuknya wujud bayi itu memiliki taraf (tahapan). Dengan kata lain bahwa 
manusia yang hidup memiliki gradasi kehidupan. Tahap wujud yang pertama adalah setelah sperma sampai di rahim dan berpadu dengan ovum (telur) wanita dan siap untuk menerima kehidupan, maka merusak tahapan ini bisa dinamakan tindak pidana. Apabila sudah menjadi segumpal daging, tingkat tindak pidananya lebih kejam. Bila telah ditiupkan ruh (berjiwa) dan telah berbentuk, maka semakin keji pidananya dan puncak kekejian ialah tindakan terhadap bayi yang telah lahir dengan berjiwa.

Dari uraian tersebut, dapat dikatakan bahwa permulaan wujud adalah dari tibanya sperma di dalam rahim dan tidak dari keluarnya sperma dari saluran pria, sebab seorang anak tidak akan terwujud hanya dengan dikeluarkannya air mani dari tubuh pria, melainkan dengan "diendapkannya" air mani tersebut di dalam rahim, seorang anak bukan tercipta dari air mani pria saja, melainkan dari gabungan kedua orang tuanya. (Abdul Aziz Masyhûrî, 47)

Al-Gazâlî mengukuhkan keabsahan coitus interruptus dengan membandingkan proses kehamilan dengan dinamika pembuatan akad dalam hukum Islam. Untuk menjadi absah, sebuah akad harus merupakan suatu tawaran (îjab) dan penerimaan (qabûl). Apabila suatu ijab ditawarkan lalu ditarik sebelum pihak lainnya menerima (qabûl), tidak ada pelanggaran atau pemutusan janji. Dalam proses kehamilan, menurut pemahaman al-Gazâlî tentang biologi reproduksi, mani si lelaki merupakan tawaran dan "cairan" si wanita harus menerimanya untuk terbentuknya suatu janin. Ia menggunakan istilah in'iqâd untuk pembuahan, yang dekat kepada kata 'aqd, janji. Apabila mani dicegah untuk mencapai "cairan" si wanita, ini adalah penarikan tawaran sebelum diterima, yakni sebelum perjanjian terjadi. Ini bukan pelanggaran. Apabila sebaliknya, yakni ada campur tangan setelah terbentuknya janin, maka hal ini dinamakan aborsi dan menurut pandangannya aborsi inilah yang merupakan pelanggaran.

Sebagai bukti pendukung, al-Gazâlî menyebutkan dua hadis Nabi saw. yang keduanya diriwayatkan oleh Jâbir. Hadis pertama, yaitu: ( Imam Muslim ibn al-Hajjaj V: 153-154.)

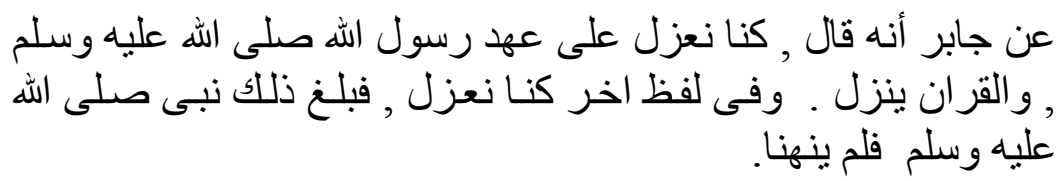

Hadis di atas menunjukkan bahwa coitus interruptus 
dipraktikkan oleh kaum Muslim di masa Nabi, dan sebagian sahabat mempraktikannya sebagai suatu tindakan kontraseptif. Ini disebutkan berulang-ulang kepada Nabi, dan Nabi tidak melarang praktik itu. Begitu juga al-Qur'an sedang diwahyukan pada masa itu, dan tidak ada larangan yang dinyatakan.

Hadis kedua yang dijadikan dasar adalah: Imam Muslim ibn al-Hajjaj al Quraisy al-Naysaburi, Sahîh., I: 610

$$
\begin{aligned}
& \text { عن جابر أن رجلا أتى رسول الله صلى الله عليه وسلم . فقال ان لى جارية هي }
\end{aligned}
$$

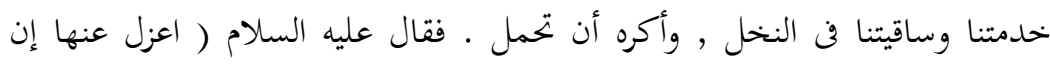

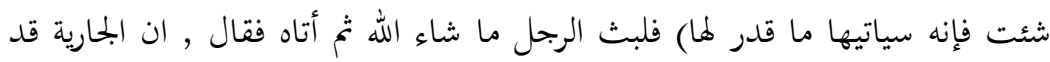

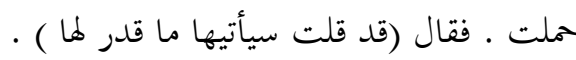

Lebih lanjut, Hukum dalam pemaknaan al-Gazâlî adalah relasi titah pembuat Hukum Syar'i dengan perbuatan manusia, al-Gazâlî menegaskan, "Tidak ada hukum tanpa khitâh (titah) dari Syâri' (Allah)." Dari statemen ini dapat dipahami bahwa hukum tidak dapat diketahui tanpa wahyu Ilahi. Atas dasar itu akal secara independen tidak dapat mengetahui baik dan buruk, maka konsekuensi logisnya adalah tidak ada Hukum Syar'i sebelum adanya penetapan wahyu. (Al-Gazâlî, 1971: 119).

Adapun kebolehan coitus interuptus secara mutlak, tanpa adanya syarat ijin istri sebagaimana dalam pandangan al-Gazâlî, hal tersebut terpengaruh dengan konsep pernikahan yang mengatakan bahwa pernikahan merupakan 'aqd tamlîk. Dengan pernikahan maka suami telah melakukan kontrak pembelian alat seks sebagai alat melanjutkan keturunan dari pihak perempuan yang dinikahinya. Pada posisi ini laki-laki adalah pemilik dan sekaligus penguasa alat seks yang ada dalam tubuh istri, sekaligus pemilik anak yang dihasilkan. Maka, untuk menentukan kapan, di mana dan menggunakan teknik apa adalah otoritas suami. Istri tidak mempunyai pilihan kecuali melayani suaminya karena melayani dan membuat suami puas adalah kewajiban baginya. (Masdar F. Mas'udi, 1998), 117-118)

Benang merah yang dapat diambil kemudian, dengan kontrak kepemilikan ini semua yang ada pada istri adalah milik suami. Konsekwensi logisnya adalah istri tidak mempunyai daya tawar dan ruang untuk memilih ketika ia tidak menghendaki praktek tersebut. 
Argumen yang mereka bangun kemudian adalah bahwa istri hanya berhak atas orgasme saja tapi tidak berhak atas ejakulasi.

Bukti bahwa al Gazâlî mempertimbangkan orgasme istri dapat kita lihat pada aturan dan tata etika hubungan seksual, di mana sebelum intercourse (memasukkan penis ke vagina), di samping suami dianjurkan untuk melakukan foreplay dengan cumbu rayu dan ciuman-ciuman terlebih dahulu, suami ketika sudah menyelesaikan hajatnya, dilarang meninggalkan istrinya dulu. Hal ini dimaksudkan agar ketika istri belum mencapai orgasme maka suami bisa membantu istri untuk mencapainya.

\section{Coitus Interuptus dalam Pandangan Ibnu al-Qayyim}

Nama lengkap Ibn al-Qayyim adalah Syamsuddin Abû Abdullah Muhammad Ibn Abî Bakar ibn Ayub Ibn Sa'ad ibn Haris az-Zar'i ad-Dimasqi. Nama al-Qayyim diambil dari jabatan ayahnya sebagai pendiri dan pengelola (al-Qayyim) madrasah, sedangkan nama al-Jauziyah berasal dari madrasah al-Jauziyah yang didirikan oleh ayahnya. (Ibn al-Qayyim, 1992: 3). Ibn Qayyim di lahirkan tahun $691 \mathrm{H} / 1292 \mathrm{M}$ dan wafat pada tanggal 13 Rajab tahun 751 H/1356 M di Damaskus. Beliau tumbuh dan berkembang di lingkungan intelektual dan ningrat. Semenjak masih usia belia ia berkecimpung di dunia ilmu pengetahuan, sehingga hal ini sangat mempengaruhi berbagai ide dan gagasan yang muncul dalam pemikirannya.

Guru yang sangat banyak mempengaruhi pemikiran Ibnu alQayyim adalah Ibn Taimiyyah. Hal ini dapat dipahami karena beliau berguru dan selalu bersama Ibn Taimiyyah sampai akhir hayatnya, selama 16 tahun. Pemikiran fiqh Ibn al-Qayyim diambil dari pemikiran fiqh Ibn Taimiyyah, bahkan Ibnu al Qayyim menggunakan metode-metode yang digunakan oleh Ibn Taimiyyah. (Muhammad alAnwar, 2001: 21)

Dalam bermazhab beliau mengikuti aliran fiqh Hanabilah, akan tetapi mazhab beliau kepada mazhab hanbali merupakan ittibâ' (mengikuti pendapat-pendapat) yang dikuatkan oleh dalil dan menolak taqlid yang tanpa dilandasi oleh dalil. Hal ini dapat dibuktikan bahwa dalam berijtihad, Ibn al-Qayyim sering beda pendapat dengan mazhab Hanabilah mengenai beberapa masalah dalam bidang fiqh. Bahkan hasil ijtihadnya sering sama dengan hasil ijtihad mazhab lain. (Muhammad al-Anwar as-Sanhuti, 39) 
Sebagaimana ulama Hanabilah, coitus interuptus menurut Ibnu al-Qayyim adalah diperbolehkan akan tetapi dengan ketentuan harus ada ijin dari istri terlebih dahulu. Ibnu al Qayyim tidak sepakat dengan pendapat Ibu Hazm yang mengatakan bahwa coitus interuptus dilarang secara mutlak dengan argumen bahwa hadis yang permisif (serba membolehkan) itu mencerminkan fakta bahwa dalam Islam segala sesuatu itu diizinkan sebelum Nabi mengeluarkan larangan khusus. Dia mengatakan bahwa Nabi telah membatalkan hadis-hadis yang permisif itu ketika beliau berkata bahwa senggama terputus merupakan "pembunuhan bayi terselubung" (al maw'udatu al sugra). Karena al-Qur'an melarang keras membunuh bayi, dan Nabi menyebut senggama terputus sebagai pembunuhan bayi terselubung.

Sanggahan yang dilontarkan Ibnu Qayyim adalah bahwa argumen Ibnu Hazm memerlukan penetapan waktu sejarah yang tepat untuk membuktikan bahwa hadis "yang membatalkan itu dikeluarkan sesudah hadis-hadis yang permisif dan bahwa penetapan waktu yang tepat itu mustahil dilakukan. Bagaimanapun juga, orang pada umumnya setuju bahwa hukum Islam yang menyatakan bahwa pembunuhan bayi hanya bisa dilakukan setelah janin terbentuk dan anak telah dilahirkan. Pembunuhan bayi seperti ini memang dilarang akan tetapi coitus interuptus tidak bisa disama dengan pembunuhan bayi.

Ulama lain, asy-Syaukani menambahkan bahwa nabi menyebut coitus interuptus sama dengan pembunuhan bayi terselubung (al maw'udatu al sugra) karena dorongan untuk melakukan kedua tindakan itu sama, yaitu melepaskan diri dari tanggungan yang lebih banyak. Tetapi pembunuhan bayi yang sesungguhnya bukan dilarang karena adanya dorongan tersebut, akan tetapi tindakan itu merupakan kejahatan yaitu menghilangkan nyawa manusia. Jadi, pelarangan di sini bukan pada coitus interuptusnya akan tetapi niat dan dorongan untuk melakukan tindakan tersebut. (Muhammad :349)

Selanjutnya, kebolehan melakukan coitus interuptus dengan syarat harus ada kerelaan istri menurut Ibnu al-Qayyim adalah karena:

- Dengan coitus interuptus maka keinginan untuk mendapatkan keturunan yang menjadi salah satu tujuan dari pernikahan tidak terpenuhi. 
- Coitus interuptus merupakan cerminan hubungan yang jelek, padahal dalam Islam selalu menganjurkan mu'âsyarah bil ma'rûf.

- Coitus interuptus bisa mengurangi bahkan menghalangi istri untuk bersenang-senang dan mendapatkan kenikmatan.

Dalil yang digunakan untuk menjustifikasi pendapatnya, Ibnu al-Qayyim di samping menggunakan hadis Jâbir sebagaimana yang digunakan oleh al-Gazâlî, ia juga mendasarkan pada hadis nabi yang lain. Adapun bunyi hadisnya yaitu: (Imam Muslim ibn al-Hajjaj al Quraisy al-Naysaburi, Sahîh V: 153-154)

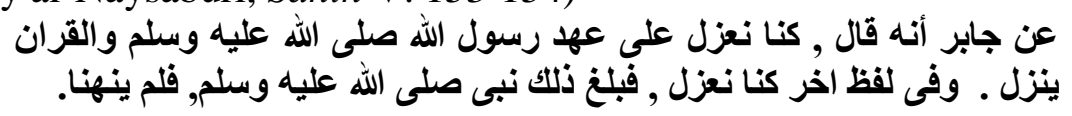

Dari argumen dan dalil yang dipakai oleh Ibnu al-Qayyim, dapat kita lihat bahwa Ibnu al-Qayyim lebih mempertimbangkan kepentingan dan hak perempuan dalam relasi seksual ini. Akan tetapi, dasar kedua yang digunakan oleh Ibu al-Qayyim, ternyata sanadnya Ibn Luhai'ah termasuk hadis da'îf. Sebagai dasar penetapan hukum, hadis da'if tidak bisa digunakan sebagai landasan atau dalil. Namun demikian, hadis tersebut sejalan dengan prinsip-prinsip fundamental (dalil qat'i) yang diajarkan oleh Islam, karena di dalamnya selain mengandung nilai-nilai musyawarah dalam urusan bersama juga mengandung adanya mu'âsyarah bil ma'rûf dalam hubungan suami istri.

Pandangan Ibnu al-Qayyim tersebut, menurut penyusun juga tidak terlepas dari pengaruh konsep pernikahan yang ia pegangi. Pernikahan bagi Ibnu al-Qayyim bukanlah 'aqd tamlîk, akan tetapi hanya 'aqd ibâhah. Dengan konsep pernikahan seperti ini, maka alat seks perempuan masih tetap menjadi milik dan hak perempuan (istri), hanya saja alat itu sudah menjadi halal dan bisa dinikmati oleh suaminya. Abdurrahman al-Jazâiri, al-Fiqh alâ Mazâhibi al-Arba'ah, (Istambul: Dâr al-Dakwah, t.t), IV: 1-3 Pada konteks ini, ada ruang dialog bagi suami dan istri untuk menentukan kapan hubungan seksual dilakukan, dengan cara seperti apa dan dimana enaknya dilakukan. Dengan demikian hubungan seks akan menjadi urusan kedua belah pihak yang tidak hanya dimonopoli satu pihak saja, karena kemesraan dan relasi seksual antara suami istri yang baik, 
disamping akan mewujudkan keluarga yang mawaddah, sakinah wa rahmah juga akan berpengaruh kepada aktifitas-aktifitas yang lain diantara mereka.

Menurut Ibnu al-Qayyim bahwa hubungan seksual pada dasarnya dilakukan untuk mencapai 3 tujuan yang mulya, yaitu:

- Melanjutkan keturunan dan menjaga kelestarian sumber daya manusia.

- Mengeluarkan sesuatu (mani) dari dalam tubuh, di mana jika menumpuk di dalam tubuh akan menimbulkan penyakit.

- Melepaskan hâjat (kebutuhan) bersenang-senang dan memperoleh kenikmatan.

Lebih lanjut, beliau menjelaskan bahwa jika air mani telah menumpuk dan berlebihan tidak segera dikeluarkan akan bisa menimbulkan penyakit, yaitu rasa bimbang, gila dan sawan. Oleh karena itu, menurutnya, manfaat bersetubuh disamping bisa menjaga pandangan mata dari niat jahat dan terpeliharanya dari zina juga bisa menghindarkan penyakit akibat tertahannya mani. (Ibnu Qayyim alJauziyah, 1994:18). Pandangan Ibnu Qayyim tentang coitus interuptus di atas dapat dilihat sebagai pandangan ulama yang menghargai hak reproduksi perempuan dalam hak menerima dan menolak hubungan seksual. Hal ini bisa dilihat pada konteks permintaan ijin suami terhadap istri ketika suami hendak melakukan coitus interuptus. Pada sisi ini sesungguhnya perempuan ditempatkan pada posisi yang setara dengan laki-laki dalam relasi seksualnya.

Di sisi lain Ibnu Qayyim juga menganjurkan foreplay dalam hubungan seksual untuk mendapatkan kepuasan bersama. Hal ini diperkuat oleh pandangan Ibnu al Qayyim bahwa coitus interuptus dapat mengurangi bahkan menghalangi istri untuk bersenang-senang dan mendapatkan kenikmatan. Oleh karena itulah beliau mensyaratkan suami untuk meminta ijin pada istri sebelum melakukan coitus interuptus. Dalam konteks ini Ibnu al Qayyim telah memperhatikan hak mendapatkan kepuasan seksual bagi istri dalam pandangannya tentang relasi seksual antara suami dan istri.

Dan lebih jauh bisa dikatakan bahwa Ibnu al Qayyim sangat mempertimbangkan langkah-langkah dalam hubungan seksual, yang dimulai dari tahap "kulo nuwun", di mana kedua pihak membangun proses kerelaan bersama yang diteruskan dengan pemanasan. Kemudian pada tahap kedua, yakni tahap "monggo" yang ditandai dengan penetrasi penis ke vagina dilakukan dan berakhir dengan 
tahap "matur nuwun", di mana kedua belah pihak telah merasakan kepuasan bersama dan saling berterima kasih.

\section{Analisis Perbandingan}

Setelah menjabarkan pendapat dan meneliti dalil serta argumen yang dipakai oleh al Gazâlî dan Ibnu al-Qayyim, di sini penyusun akan melanjutkan penelitian ini dengan analisis komparatif, yaitu akan membandingkan pendapat kedua tokoh tersebut dengan memetakan persamaan dan perbedaan di antara mereka untuk kemudian dicari di antara keduanya yang lebih menghargai hak-hak seksual perempuan.

\section{Segi Penetapan Hukum}

\section{Persamaan.}

Persamaan yang terlihat dari pendapat yang dilontarkan, baik alGazâlî maupun Ibnu al-Qayyim adalah mereka sama-sama menyatakan kebolehan melakukan coitus interuptrus. Adapun pendapat yang melarang secara mutlak dengan menyamakan tindakan tersebut dengan pembunuhan terselubung menurut mereka tidaklah terbukti baik argumen maupun dalil yang dipakai.

\section{Perbedaan.}

Meskipun al-Gazâlî dan Ibnu al-Qayyim sama-sama membolehkan, akan tetapi mereka berbeda dalam menentukan ada atau tidaknya syarat yang mengikuti kebolehan coitus interuptus. AlGazâlî mengatakan kebolehan secara mutlak, dengan arti bahwa tidak ada syarat yang mengikuti kebolehan tersebut. Sedangkan menurut Ibnu al-Qayyim, Coitus interuptus tersebut boleh dilakukan apabila ada ijin dari istri. Kebolehan di sini ada syarat yang mengikutinya, mafhum mukhalahnya kemudian adalah jika istri tidak mengijinkan berarti syarat yang mengikuti kebolehan coitus interuptus tidak terpenuhi, maka secara otomatis coitus interuptus tidak boleh.

\section{Segi Dalil dan Argumen}

Persamaan.

Pada dasarnya, baik al-Gazâlî maupun Ibnu al-Qayyim sama sama menggunakan hadis yang diriwatkan oleh Jâbir dalam menguatkan 
pendapat mereka berdua. Argumen yang mereka berdua bangun pun sama-sama disandarkan pada biologi reproduksi. Bahwa tindakan coitus interuptus tidak sama dengan pembunuhan bayi (abortus). Pembunuhan bayi hanya bisa dilakukan setelah janin terbentuk, sedangkan terbentuknya janin adalah harus ada pertemuan antara sperma dan ovum. Padahal dalam coitus interuptus sperma dikeluarkan di luar vagina sehingga tidak sampai pada rahim (ovum).

Perbedaan.

Selain menggunakan dalil hadis yang diriwayatkan oleh Jâbir, Ibnu al-Qayyim juga menggunakan hadis yang datangnya dari Umar bin Khattab. Hadis ini menyatakan pencegahan coitus interuptus pada wanita merdeka kecuali dengan seijin wanita tersebut. Argumen Ibnu al-Qayyim adalah bahwa dalam coitus interuptus setidaknya ada hakhak istri yang tidak bisa diperoleh dan dinikmati. Oleh karena itu meminta ijin untuk mengambil hak tersebut adalah wajib. Lain halnya dengan al-Gazâlî yang tidak mendasarkan pendapatnya pada hadis dari Umar R.A. Menurutnya seorang istri dalam hubungan seksual hanya berhak atas orgasme saja tidak berhak atas ejakulasi.

\section{Segi Hak Mendapat Kepuasan Seksual}

\section{Persamaan.}

Hak mendapatkan kepuasan seksual adalah hak yang dimiliki oleh laki-laki dan perempuan dalam menikmati hubungan seksual. Dalam hubungan seksual ada dua aspek yang harus diperhatikan oleh suami maupun istri yakni fase dan langkah dalam hubungan seksual. Pada aspek fase dalam hubungan seksual yang meliputi fase kebangkitan, peningkatan rangsangan, orgasme dan resolusi, kedua ulama ini sepakat bahwa orgasme perempuan merupakan salah satu aspek penting dalam aturan atau etika berhubungan.

Perbedaan.

Akan tetapi pada aspek langkah dalam melakukan hubungan seksual kedua ulama ini berbeda pandangan. Adapun langkah dalam melakukan hubungan seksual meliputi "kulo nuwun" yang merupakan langkah kerelaan kedua belah pihak dengan adanya saling mengijinkan yang diteruskan dengan pemanasan (foreplay), "monggo" yang merupakan tahap penetrasi penis ke dalam vagina 
dan tahap "matur nuwun" setelah keduanya merasakan kepuasan bersama. Pada dataran ini al Gazali mengesampingkan tahap "kulo nuwun" karena beliau membolehkan suami melakukan coitus interuptus tanpa harus meminta ijin dari istri terlebih dahulu. Padahal tahap ini adalah tahap kerelaan yang harus dilalui kedua belah pihak dalam melakukan hubungan seksual. Sedangkan Ibnu al Qayyim mensyaratkan ijin istri dalam melakukan coitus interuptus, sehingga tahap "kulo nuwun" menurut Ibnu al Qayyim adalah suatu tahap yang harus diperhatikan oleh suami dan istri demi terciptanya kerelaan dan kesetaraan dalam berhubungan seksual.

Setelah melakukan mapping terhadap penetapan hukum, dalil dan argumentasi dari kedua tokoh tersebut, dapat dilihat bahwa kedua pendapat di atas sesungguhnya mengalir dari konsep pernikahan itu sendiri. Al-Gazâlî yang menganggap bahwa coitus interuptus boleh secara mutlak, tanpa harus ijin istri berpandangan bahwa nikah itu adalah 'aqd tamlîk (aqad untuk memiliki). Seorang perempuan yang telah menikah berarti telah menyerahkan miliknya, termasuk milik yang paling pribadi itu kepada suaminya. Konsekuensinya, segala kemauan suaminya menjadi kewajiban bagi isteri untuk melayaninya. Alat reproduksi isteri adalah milik suami, demikian juga anak yang akan dilahirkannya adalah milik suami pula.

Meskipun demikian, penyusun masih melihat celah prinsip mu'âsyarah bil ma'rûf dalam pandangan al-Gazâlî, di mana ketika melakukan hubungan seksual suami diharuskan melakukan foreplay terlebih dahulu, sebagai salah satu cara untuk membantu istri mengalami orgasme. Walaupun begitu, masih ada hak istri lain yang masih tidak bisa didapatkan sehubungan dengan coitus interuptus, hak tersebut yaitu hak untuk hamil dan memiliki anak. Dengan tertumpahnya sperma di luar rahim, maka pembuahan tidak akan terjadi sehingga keinginan perempuan untuk memiliki anakpun tidak bisa didapatkan.

Adapun Ibnu al-Qayyim yang membolehkan coitus interuptus asalkan ada ijin dari istrinya, beranggapan bahwa dalam coitus interuptus harus memperhatikan hak-hak istri, dengan dilakukan praktek ini maka hak menikmati hubungan seksual sulit untuk didapatkan karena tidak sempurnanya senggama. Disamping itu hak untuk mendapatkan anak yang diidamkan oleh perempuan pun tidak bisa dicapai. Pandangan seperti ini, pada dasarnya, berpangkal pada konsep pernikahan. Pernikahan hanya sebagai 'aqd ibahah (aqad 
untuk membolehkan). Artinya, melalui pernikahan seorang suami yang sebelumnya haram menikmati hubungan seksual dengan isterinya, kini menjadi halal. Dengan demikian alat reproduksi sang isteri tetap menjadi milik sang isteri, hanya saja kini boleh dinikmati oleh sang suami. Dalam hal menikmati tersebut bukan saja urusan suami, tapi juga urusan isteri.

\section{Simpulan}

Al-Gazâlî yang nota bone ulama Syâfi'iyyah, membolehkan coitus interuptus secara mutlak. Sebagai upaya pencegahan kehamilan, coitus interuptus sudah dilakukan sejak zaman Nabi Muhammad SAW. Hal ini dibuktikan dengan adanya praktek tersebut dan Nabi tidak melarang. Dalil yang dipakai al-Gazâlî adalah hadis yang diriwayatkan oleh Jâbir dan hadis ini termasuk sahîh. Disamping itu, tidak ada satupun nas yang secara jelas menyatakan larangan tindakan coitus interruptus. Bolehnya coitus interruptus secara mutlak didasarkan pada pemahamannya mengenai biologi reproduksi manusia dan dengan membandingkan tindakan coitus interruptus dengan suatu akad (ijâb dan qabûl). Dengan kebolehan secara mutlak, bahwa seorang suami boleh melakukan praktek ini tanpa harus minta ijin pada istrinya, hal ini terkait dengan konsep pernikahan yang dipahaminya. Pernikahan merupakan aqd tamlîk. Posisi perempuan di sini telah dibeli oleh suami untuk dijadikan istri. Oleh karena itu, secara otomatis istri telah menjadi milik suami secara mutlak. Pernikahan disini adalah kepemilikan. Dengan akad maka suami telah membeli perangkat seksual istri. Meskipun alGazâlî membolehkan secara mutlak dalam coitus interuptus, dalam tata aturan hubungan seksual, ia masih memberikan aturan main yang sopan, dimana sebelum intercourse, suami harus melakukan foreplay (pemanasan) terlebih dahulu. Hal ini sejalan dengan argumen mereka bahwa dalam hubungan seksual istri hanya berhak atas orgasme saja tapi tidak berhak atas ejakulasi.

Hampir sama dengan al-Gazâlî, Ibnu al-Qayyim juga membolehkan praktek coitus interuptus tapi dengan syarat ada ijin istri terlebih dahulu. Mafhum mukhalafahnya adalah ketika istri tidak mengijinkan, maka coitus interuptus tidak boleh dilakukan. Pandangan ini juga dipengaruhi oleh konsep pernikahan. Pernikahan bagi ibnu al-Qayyim adalah 'Aqd Ibâhah. Pernikahan hanyalah 
kontrak untuk membolehkan sesuatu, yaitu hubungan seksual yang pada awalnya dilarang. Pada posisi ini istri masih tetap berhak dan pemilik atas perangkat seksualnya. Dalam coitus interuptus, setidaknya ada hak-hak istri yang tidak terpenuhi, yaitu kehamilan dan kenikmatan seksual. Dalil yang digunakan Ibnu al-Qayyim atas pembolehan coitus interuptus sama dengan al-Gazâlî, yaitu hadis dari Jâbir tentang pembolehan praktek ini sebagai upaya pencegahan kehamilan pada waktu itu. Dari kesimpulan ini dapat kita lihat bahwa pandangan Ibnu al-Qayyim lebih memperhatikan hak-hak perempuan dibanding dengan pandangan al-Gazâlî karena ijin istri dijadikan syarat atas kebolehan coitus interuptus. 


\section{DAFTAR PUSTAKA}

Abû Bakar, Alauddin Ibnu Mas'ûd Al Kâsâniy, 1996. Badâi' al Sanâi' fi Tartîbi asy Syarâ'I, Beirût: Dâr al Fikr.

Agustian, T. 2020. Demokrasi Islam dalam Pandangan Muhammad Natsir dan Muhammad Abid Al-Jabiri. EL-Ghiroh, 18(01), 724.

Al Jauziyyah, Ibnu Qayyim. 1992 Zâd al Ma'âd fì Hadyi Khair al'Ibâd, Beirût: Dâr al Kutub al 'Ilmiyyah.

Ali engineer, Asghar. 2000. Hak-hak Perempuan Dalam Islam, (Yogyakarta: Lembaga Studi dan Pengembangan Perempuan dan Anak

Bakker, Anton. 1992. Metodologi Penelitian Filsafat, Yogyakarta: Kanisius.

Fakih, Mansour . 1999. Analisis Gender dan Transformasi Sosial, Yogyakarta: Pustaka Pelajar.

Hakim, Rahmat. 2000. Hukum Perkawinan Islam, Bandung: Pustaka Setia.

Hâmid al Gazâlî, Abû. 1975. Ihyâ 'Ulûm al Dîn, Beirût :Dâr al Fikr.

Inayatul Ulya, Nunuk. 2001. 'Azl Sebagai Upaya Pencegahan Kehamilan: Studi Atas Pandangan Ibnu Hazm, Skripsi pada Fakultas Syari'ah IAIN Raden Intan Lampung.

Masdar F. Mas'udi, 2000. Islam dan Hak-hak Reproduksi Perempuan, Bandung: Mizan.

Mukhtar, Kamal. 1993. Asas-asas Hukum Islam tentang Perkawinan, Jakarta: Bulan Bintang

Musallam, B.F. 1985. Seks dan Masyarakat dalam Islam, terj. Rahmani Astuti, Bandung: Pustaka. 
118 Tomi Agustian Dan Lentiara Putri, Coitus Interuptus....

Subhan, Zaitunah. 1999. Tafsir Kebencian: Studi Bias Gender dalam Tafsir al-Qur'an, Yogyakarta; Lembaga Kajian islam dan Sosial (LKIS)

Surtiretna, Nine. 2001. Bimbingan Seks Suami Istri: Pandangan Islam dan Medis, Bandung: Remaja Rosdakarya

T. Gilarso S.J. 1990. Moral Keluarga, Yogyakarta: IKIP Sanata Darma.

Umar, Nasarudin. 1999. Kodrat Perempuan Dalam Islam, Jakarta: Lembaga Kajian Agama dan Jender.

Yasir Alimi, Moh. 1999. Advokasi Hak-hak Perempuan: Membela Hak Mewujudkan Perubahan, Yogyakarta: Lembaga Kajian Islam dan Sosial. 